\title{
Ativismo Negr@: entrecruzando epistemologias feministas nas trajetórias de mulheres negras e religiosas ${ }^{1}$
}

\author{
Manoelle Lopes Fontes 2 iD
}

Programa de Pós-Graduação em Relações Étnicas e Contemporaneidade

\section{Ana Claudia Lemos Pacheco ${ }^{3}$}

Universidade do Estado da Bahia

\section{Dossiê | Dossier | Dosier \\ DOI do artigo: 10.22481/odeere.v6i01.8734 RESUMO}

Neste artigo propomos discutir as trajetórias e encruzilhadas de mulheres negras adeptas do catolicismo e do candomblé, a partir da análise subsidiada por epistemologias situadas no campo do Ativismo Negr@, tomando como referência o feminismo negro e decolonial e a teologia feminista católica, procurando captar as narrativas sobre corpo, sexualidade, etnia, raça e religiosidade, de onde emergem intersecções. Para fazermos esse diálogo, contamos com as trajetórias de duas mulheres negras sul baianas, residentes no município de Canavieiras, autodeclaradas negras, com idades de 52 e 61 anos, sendo uma católica e outra candomblecista, respectivamente. As "trajetórias em narrativas" das duas colaboradoras da pesquisa nos revelaram encruzilhadas de pontos de vista sobre corpo e sexualidade, em que a religiosidade norteava a mobilização de diferentes conceitos e representações sobre o gênero. Nesse sentido, o corpo aparece narrado de diferentes formas, sobretudo como ferramenta para o acesso e a manutenção das práticas religiosas, que através da legitimação de elementos sacralizados permitem a efetivação e veiculação de crenças e valores que atravessam o campo da moralidade, afetando, assim, as percepções sobre os desejos e as práticas sexuais de mulheres negras.

Palavras-chave: Mulheres negras; Religiosidades; Encruzilhada; Interseccionalidade; Canavieiras.

\section{Black Activism: intertwining feminists epistemologies in the trajectories of black and religious women ABSTRACT}

In this article, we propose to discuss the trajectories and crossroads of black women adept of Catholicism and Candomblé, based on analysis subsidized by epistemologies on the black activism field, our references were Black and decolonial feminism as well as Catholic feminism theology, we try to catch narratives about body, sexuality, ethnicity, race, and religiosity from where intersections emerge. To make these connections, we rely on the trajectories of two black women from the south of Bahia, residing in the municipality of Canavieiras, who self-declared as black women, aged 52 and 61 years old, one is Catholic the other one is Candomblecist, respectively. The "trajectories in narratives" of the two research collaborators have unveiled a crossroads of viewpoints about body and sexuality, in which religiosity guided the mobilization of different concepts and representations about gender. With this regard, "body" is narrated in different ways, especially as a tool for accessing and maintaining religious practices, which through the legitimation of sacred elements allows the fulfillment and diffusion of beliefs and values that the field of morals, affecting perceptions about lust and sexual practices of black women.

Keywords: Black women; Religiosities; Crossroads; Intersectionality; Canavieiras.

Submetido em: 15 de mai. de 2021 | Aceito em: 01 de jun. de 2021

'Esse artigo é resultado da pesquisa a nível de mestrado acadêmico, financiada pela Fundação de Amparo à Pesquisa do Estado da Bahia - FAPESB.

2 Mestranda em Relações Étnicas e Contemporaneidade - PPGREC/UESB. Licenciada em Ciências Sociais - UESC. Membro do Grupo de Pesquisa CANDACES: gênero, raça, cultura \& sociedade da UNEB, certificado pelo CNPq. E-mail: manufonts19@gmail.com

3 Professora Titular de Sociologia da Universidade do Estado da Bahia (UNEB, Campus- I, Salvador) e Professora Permanente do Mestrado acadêmico de Relações Étnicas e Contemporaneidade da Universidade Estadual do Sudoeste da Bahia, Campus Jequié, Bahia. Líder do Grupo de Pesquisa CANDACES: gênero, raça, cultura \& sociedade da UNEB, certificado pelo CNPq. E-mail: ana_pachecau@hotmail.com 
Lopes, M. L., Pacheco, A. C. L., Ativismo Negr@: entrecruzando epistemologias feministas nas trajetórias de mulheres negras e religiosas. ODEERE, v. 6, n. 01, jan./jun., p. 38-66, 2021. https://doi.org/10.22481/odeere.v6i01.8734

\section{I.INTRODUÇÃO}

Este artigo tem como proposta discutir a respeito das trajetórias encruzilhadas de mulheres negras e religiosas, tomando como referências dimensões interseccionais com relação ao corpo e a sexualidade nas experiências de adeptas do catolicismo e do candomblé, que cimentam terreno que historicamente tencionam relações de poder no contexto brasileiro, a partir da análise subsidiada por diferentes epistemologias feministas, situadas no campo do Ativismo Negr@, do feminismo negro e decolonial e da teologia feminista católica, produzidas em dissidência com o cis-hétero-patriarcado branco e eurocêntrico.

Tomamos como base o lugar de reflexão da encruzilhada, como universo de significação pertencente às tradições religiosas de matriz africana ${ }^{4}$, na produção do pensamento intelectual negro-diaspórico e situada sobre a dimensão do conceito de "espaços de contribuições"5, para discutir acerca das trajetórias, a partir do entrecruzamento de epistemologias feministas. Esse conceito de encruzilhada permite discutir as similaridades e diferenças entre sujeitas cujos corpos colonizados estão submetidos às violências interseccionais, em que são aproximadas principalmente por gênero e raça, compreendendo que o deslocamento entre experiências individuais e coletivas se dão justamente por meio do cruzamento entre biografias de mulheres no fluxo de relações transnacionais. Além de contribuir para evidenciar que, ainda que diferentes experiências sejam adquiridas dentro ou fora da academia ou do campo do ativismo, as diferentes realidades de mulheres negras são atravessadas pelas vias da exploração colonial e dos danos provocados pelo racismo e pelo sexismo.

Nesse sentido, verificando estas intersecções no que diz respeito ao recorte entre religiosidades distintas, a dimensão da encruzilhada comporta discussões no tocante as produções de diferentes epistemologias feministas, de onde emergem diversas perspectivas em relação aos corpos femininos e as sexualidades a partir de relações históricas produzidas no seio da sociedade, dentro de religiosidades e

\footnotetext{
${ }^{4}$ Dentro dessas tradições a encruzilhada representa instância simbólica e ritualizada que possibilita - centramento e descentramento, a unidade, multiplicidade em que principalmente no candomblé simbolizam a referência à Exú, dono dos caminhos e divindade da comunicação que atua como mensageiro e intermediário entre o mundo material e as outras divindades.

${ }^{5}$ AUGUSTO, Geri. Transnacionalismo negro: a encruzilhada de amefrican@s. Revista da FAEEBA Educação e Contemporaneidade, v. 25, 2016, (p. 25-38).
} 
Lopes, M. L., Pacheco, A. C. L., Ativismo Negr@: entrecruzando epistemologias feministas nas trajetórias de mulheres negras e religiosas. ODEERE, v. 6, n. 01, jan./jun., p. 38-66, 2021. https://doi.org/10.22481/odeere.v6i01.8734

de instituições sociais circunstanciadas por colonialidades. Os diferentes campos epistemológicos destacados neste estudo assentam perspectivas distintas, dados seus contextos de criação e a característica do ativismo das sujeitas que os produzem, pois mobilizam diferentes categorias de análise para revisitar e tensionar cosmologias, crenças e instituições religiosas a partir de relações desiguais tecidas dentro destas, contudo, não se pretende aqui esgotar todas as discussões.

De modo geral, as produções do feminismo negro e das teologias feministas permitem observar que o catolicismo e o candomblé possuem diferentes concepções com relação aos corpos femininos e as sexualidades, em relação à constituição do conservadorismo cristão e do acionamento de bases cosmológicas e rituais presentes nas tradições de matriz africana.

A abordagem dessas epistemologias na pesquisa em análise, se deu pelo investimento por um deslocamento tanto epistemológico como metodológico no entrecruzamento de "trajetórias em narrativas" 6 , para analisar a articulação entre biografias de mulheres negras e religiosas. Visando contribuir para o projeto de construção do conhecimento a respeito de mulheres negras e para mulheres negras, a partir do lugar de contribuição das intelectuais negras, principalmente no que se refere às especificidades de povos na América Latina/Amefrica Ladina7 que têm demandado outras formas de pensar a produção de feminismos a partir de matrizes interseccionais e descolonizadoras, como parte dos saberes críticos e emancipatórios construídos pelo Ativismo Negr@8.

\footnotetext{
${ }^{6}$ KOFES, Suely. Narrativas biográficas: que tipo de antropologia isso pode ser? In: KOFES, Suely; MANICA, Daniela (org). Vida e grafia: narrativas antropológicas entre biografia e etnografia. Rio de Janeiro: Lamparina Editora, 2015, (p. 20 -38).

${ }^{7}$ Amefrica Ladina é um conceito que se refere às singularidades das heranças africanas no processo de formação cultural e étnica de sociedades latino-americanas. Baseando neste lugar de interpretação, o conceito de amefricanidade foi cunhado por Lélia Gonzalez em 1988, tendo como objetivo identificar democraticamente o lugar das experiências compartilhadas por mulheres e homens racializados, ampliando democraticamente um campo de referência político e cultural para grupos marginalizados em contexto da diáspora. A aplicação do conceito aponta para o que a autora concebeu como a afirmação de subjetividades historicamente forjadas e comumente compartilhadas por amefricanas e amefricanos em diferentes contextos socioculturais, que se assentam por processos de resistências e expressões étnicas e culturais afrocentradas na América Latina. Vide: GONZALEZ, Lélia. A categoria político-cultural de amefricanidade. Tempo Brasileiro, Rio de Janeiro, n. 92/93,1988, (p. 69-82).

${ }^{8}$ GOMES, Nilma Lino. O movimento negro educador: saberes construídos nas lutas por emancipação. Petrópolis, Rio de Janeiro: Vozes, 2017.
} 
Lopes, M. L., Pacheco, A. C. L., Ativismo Negr@: entrecruzando epistemologias feministas nas trajetórias de mulheres negras e religiosas. ODEERE, v. 6, n. 01, jan./jun., p. 38-66, 2021. https://doi.org/10.22481/odeere.v6i01.8734

\section{Vidas cruzadas: apresentando as nossas colaboradoras}

As informações e discussões levantadas nesse artigo resultaram de uma pesquisa em grau de mestrado acadêmico realizada com duas colaboradoras de pesquisa residentes em Canavieiras, autodeclaradas negras, com idades de 52 e 61 anos, sendo uma católica e outra candomblecista, respectivamente. Estas são mulheres cis-gênero, negras, religiosas, de classe trabalhadora, heterossexuais e já na fase madura de suas vidas, com relação as quais nos referimos através dos nomes fictícios9 de Madalena e Belmira. A pesquisa teve como problemática investigar como essas mulheres produziam significados e/ou ressignificam seus corpos e sexualidades na encruzilhada de gênero, da etnia, da raça e da classe a partir da religiosidade ${ }^{10}$. Para responder aos seguintes questionamentos: Como as religiosidades impactaram as relações dessas mulheres com seus corpos e sexualidades? E como suas trajetórias em Canavieiras se aproximaram ou se distanciaram nas encruzilhadas, considerando o processo de subjetivação remanescente na sociedade cacaveira? A seguir, a título de conhecimento e familiarização, sinalizamos aos leitores e leitoras breves informações no que diz respeito às suas biografias.

\section{Madalena: "vivendo em pecado"}

Madalena estava com 52 anos de idade quando realizamos a entrevista para a pesquisa. Ela é mãe de dois filhos, avó de uma neta, oriunda de família de classe trabalhadora e com baixa renda. Nasceu na zona rural de Canavieiras no período da efervescência das lavouras cacaueiras e ainda criança trabalhava nas roças de cacau realizando serviços na plantação e nas colheitas. Após o

\footnotetext{
${ }^{9}$ Pela natureza do estudo em uma cidade de interior consideramos pertinente a utilização de nomes fictícios para garantir os valores éticos de preservação das identidades das colaboradoras de pesquisa.

${ }^{10}$ Partimos da noção de religiosidade como a dimensão da prática pessoal empreendida para estabelecer conexões com diferentes elementos de ordem sagrada e/ou divina, baseada em crenças e rituais que norteiam as formas de perceber o mundo e explicar a realidade vivida, mas que independe diretamente de uma relação institucionalizada. Portanto, compreendemos essa diferenciação entre os termos religiosidade e religião, em que este último se refere a dimensão institucional que Geertz (2008), descreve como um sistema de símbolos que mobiliza conceitos e códigos organizacionais e que atua a partir de disposições sobre os/as sujeitos/as. GEERTZ, Clifford. A religião como sistema cultural. In . A interpretação das culturas. Rio de Janeiro: LTC, 2008, (p. 65-91).
} 
Lopes, M. L., Pacheco, A. C. L., Ativismo Negr@: entrecruzando epistemologias feministas nas trajetórias de mulheres negras e religiosas. ODEERE, v. 6, n. 01, jan./jun., p. 38-66, 2021. https://doi.org/10.22481/odeere.v6i01.8734

falecimento do pai, Madalena migrou para a zona urbana do município com a mãe e os irmãos, sendo levada a exercer a profissão de empregada doméstica com apenas sete anos de idade. Desde então, ela nunca conseguiu migrar para outra profissão, mesmo que um dia tenha sonhado em ser professora, desejo que não conseguiu realizar porque precisava trabalhar nos horários das aulas de magistério, tendo conseguido concluir o ensino médio apenas em idade adulta. Ainda quando jovem Madalena se casou, aos 19 anos, e teve dois filhos deste relacionamento. Dentro dessa realidade, entrou em contato com a religiosidade católica e escolheu vivenciá-la integrando-se na comunidade religiosa de Canavieiras por volta dos vinte e poucos anos, participando de grupos de canto, sendo professora de catequese e realizando serviços não remunerados como zeladora da igrejinha do bairro onde residia.

Contudo, após mais de vinte anos casada Madalena separou-se devido aos conflitos vivenciados com o antigo companheiro. No momento da pesquisa ela estava numa relação conjugal informal, dividindo um lar com outro companheiro, mas utiliza o status civil de solteira. No intercurso dessas relações, Madalena passou por diferentes fases em sua trajetória, permanecendo no catolicismo ao longo de mais de trinta anos. Nesse processo, essa religiosidade dinamizou diferentes dimensões da vida de Madalena, principalmente no aspecto da afetividade e da sexualidade, especialmente a partir de suas interpretações sobre "viver em pecado" por vivenciar uma segunda relação que não foi legalizada pela instituição religiosa, assim como, também dinamizou o modo como ela passou a interpretar seu corpo e no tocante as relações interpessoais dentro e fora da comunidade católica.

\section{Belmira: "solteira e feliz"}

Belmira tinha 61 anos quando realizamos a entrevista. Ela é mãe de três filhos e avó que ajudava a criar uma de suas netas. Oriunda de família de classe trabalhadora e com baixa renda, Belmira nasceu na cidade de Caravelas e aos seis anos de idade mudou-se junto com a família para Canavieiras. Possuía ensino médio completo, com ênfase em magistério, concluído em idade adulta, mas nunca atuou como professora na educação formal, pois migrou entre diferentes postos de prestação de serviço ao longo da vida, conseguindo aposentar-se havia 
Lopes, M. L., Pacheco, A. C. L., Ativismo Negr@: entrecruzando epistemologias feministas nas trajetórias de mulheres negras e religiosas. ODEERE, v. 6, n. 01, jan./jun., p. 38-66, 2021. https://doi.org/10.22481/odeere.v6i01.8734

poucos anos como pescadora artesanal, contabilizando uma renda mensal de um salário-mínimo, que necessitava ser complementada com a realização de trabalhos artesanais. Belmira já foi casada com o pai de seus filhos, mas separouse anos atrás e declarava com ênfase a sua decisão por manter o status civil como solteira, apresentando-se como "solteira e feliz". No percurso de sua trajetória, a religiosidade candomblecista adentrou a vida de Belmira a partir de influências familiares, sobretudo através de sua mãe.

Porém, foi apenas após tornar-se adulta que Belmira tomou a decisão de vivenciar de fato a religiosidade, o que foi um marco importante em sua vida, por ter provocado mudanças, principalmente relacionadas à forma como passou a vivenciar a afetividade e a sexualidade, optando por se tornar celibatária por volta dos quarenta e oito anos de idade. Deste modo, no contexto de realização da entrevista com esta colaboradora, já havia por volta de quatorze anos que Belmira tinha sido iniciada em um terreiro de candomblé em outro município e contribuía no combate à discriminação em relação as religiões de matriz africana em Canavieiras, principalmente através das ações relacionadas às manifestações culturais afro-brasileiras que faziam parte de sua vida desde a infância.

Partindo da análise das trajetórias destas colaboradoras de pesquisa, utilizamos da metodologia de abordagem biográfica, mediante a coleta de histórias de vida por meio de entrevistas narrativas como instrumento de pesquisa e de análise para alcançar aspectos pertinentes das vivências de Madalena e Belmira, ao fundir suas histórias de vida em termos de experiências individuais e coletivas, que informam acerca do social e o político à luz dos conflitos interseccionais ${ }^{11}$. As entrevistas foram realizadas na residência das colaboradoras de pesquisa em Canavieiras, entre os meses de outubro e dezembro de 2019, com duração média de uma hora cada. A dimensão das biografias articuladas em meio à recomposição de trajetórias na produção de pesquisas fora acionada a partir da recomposição de fatos vivenciados, interpretados e narrados pelas colaboradoras, em que as dimensões das experiências emergiram no tocante ao

"KOFES, Suely. Experiências sociais, interpretações individuais: histórias de vida, suas possibilidades e limites. Cadernos Pagu, n. 3, 1994, (p. 117-141). 
Lopes, M. L., Pacheco, A. C. L., Ativismo Negr@: entrecruzando epistemologias feministas nas trajetórias de mulheres negras e religiosas. ODEERE, v. 6, n. 01, jan./jun., p. 38-66, 2021. https://doi.org/10.22481/odeere.v6i01.8734

campo das singularidades ${ }^{12}$, a partir da dimensão histórica dos corpos femininos negros constituídos ao longo das sociedades colonizadas.

Isto posto, ao longo desse artigo buscamos discutir como o corpo e as sexualidades articulados por demandas religiosas podem ser produzidos a partir de outros significados que transcendem as "imagens de controle"13 que historicamente têm aprisionado e estereotipado os corpos negros, no contexto de pesquisas científicas, contribuindo para o tensionamento entre narrativas, objetivando descolonizar imaginários a respeito de mulheres negras sul baianas, destacando as tramas sobre as quais estão tecidos seus corpos dentro das vivências no catolicismo e no candomblé.

\section{Ativismo Negr@ na encruzilhada epistemológica: feminismo negro e decolonial e teologia feminista católica - leituras sobre trajetórias de mulheres negras}

A potência histórica da resistência negra na diáspora, em suas diversas artimanhas em prol da sobrevivência étnica durante 0 processo de desumanização colonial foi catalisadora na constituição política do Movimento Negro contemporâneo e de Mulheres Negras ${ }^{14}$, principais protagonistas na luta por "correções das desigualdades raciais desenvolvidas pelo Estado brasileiro 15, especialmente no que se destacam as ações afirmativas e a produção de saberes pautados no resgate e na valorização da ancestralidade afro-diaspórica.

A força histórica do Ativismo Negr@ tem contestado as bases dos discursos ideológicos relativamente a sociedade brasileira, sobretudo no que se destaca o mito da democracia racial, visando discutir a emergência da cidadania negra e politizando a "raça" como estrutura constitutiva das desigualdades experienciadas pela população negra. Dentro desta demanda, o ativismo de mulheres negras tem sido essencial para denunciar a articulação do gênero e da raça a respeito de seus corpos, apontando as dimensões do racismo e do sexismo como principais

\footnotetext{
${ }^{12}$ KOFES, Suely; PISCITELLI, Adriana. Memórias de "histórias femininas, memórias e experiências". Cadernos Pagu, v. 8, 1997, (p. 343-354).

${ }^{13}$ COLLINS, Patricia Hill. Aprendendo com a outsider within: a significação sociológica do pensamento feminista negro. Sociedade e Estado, v. 31, 2016, (p. 99-127).

${ }^{14}$ GONZALEZ, Lélia. Por um feminismo afro-latino-americano: ensaios, intervenções e diálogos. RIOS, Flávia; LIMA, Márcia (Orgs.). Rio de Janeiro: Zahar, 2020.

${ }^{15}$ GOMES, Nilma Lino. O movimento negro educador: saberes construídos nas lutas por emancipação. Petrópolis, Rio de Janeiro: Vozes, 2017, (p. 18).
} 
Lopes, M. L., Pacheco, A. C. L., Ativismo Negr@: entrecruzando epistemologias feministas nas trajetórias de mulheres negras e religiosas. ODEERE, v. 6, n. 01, jan./jun., p. 38-66, 2021. https://doi.org/10.22481/odeere.v6i01.8734

elementos que orquestram ao longo da história a superexploração da mulher negra na sociedade brasileira - tanto no campo do trabalho, como no campo sexual -, questões que foram negligenciadas pela presença do racismo no Movimento de Mulheres e do sexismo no Movimento Negro 16. Logo, "a ação das ativistas negras constrói saberes e aprendizados políticos, identitários e estéticocorpóreos específicos"17 que têm ressignificado a luta antirracista e antissexista no Brasil.

Decerto, o Ativismo Negr@ fruto das lutas por emancipação, instituídas especialmente no século XX, tem contribuído para a produção de conhecimentos no tocante a realidade da população negra no Brasil, sobretudo relativamente aos marcadores interseccionais que estruturam as desigualdades sociais, políticas e econômicas e que contestam as bases dos conhecimentos hegemônicos instituídos a partir da lógica eurocentrada. Situando a produção do conhecimento com base na experiência histórica de negros e negras na diáspora africana, o Movimento Negro contemporâneo e de Mulheres Negras produzem e articulam "saberes de grupos não hegemônicos e contra hegemônicos" dentro dos diferentes campos na produção do conhecimento científico, que têm tensionado a produção epistemológica em diferentes áreas do conhecimento ${ }^{18}$.

Localizando a produção do conhecimento situado neste Ativismo Negr@, diferentes estudos destacaram que o protagonismo de mulheres negras no candomblé contribuiu para a consolidação das organizações religiosa e política no Brasil, em que africanas e suas descendentes circunstanciadas pela violência escravocrata foram essenciais para garantir a sobrevivência étnica afro-diaspórica frente aos processos de apagamento sofridos ao longo da história ${ }^{19}$. Dentro deste

${ }^{16}$ GONZALEZ, Lélia. Racismo e sexismo na cultura brasileira. Revista Ciências Sociais Hoje, v. 2, 1984, (p. 223-244); GONZALEZ, Lélia. A mulher negra na sociedade brasileira. In: Primavera para as rosas negras: Lélia Gonzalez em primeira pessoa. Rio de Janeiro: Diáspora Africana, UCPA, União dos Coletivos Pan-Africanistas, 2018, (p. 34-53).

17id., O movimento negro educador: saberes construídos nas lutas por emancipação. Petrópolis, Rio de Janeiro: Vozes, 2017, (p. 73).

${ }^{18}$ lbid., (p. 16).

${ }^{19} \mathrm{No}$ Brasil algumas pesquisas pioneiras trataram desta temática, evidenciando a centralidade e o protagonismo das mulheres negras no processo de consolidação e de resistência das tradições africanas reinterpretadas na diáspora, como no caso da religiosidade do candomblé. Destacando algumas destas pesquisas têm-se: LANDES, Ruth. A cidade das mulheres. Rio de Janeiro: Civilização Brasileira, 1967; BERNARDO, Teresinha. Negras, mulheres e mães: lembranças de Olga de Alaketu. São Paulo: Arole Cultural, 2019; WERNECK, Jurema Pinto. Samba segundo as ialodês: mulheres 
Lopes, M. L., Pacheco, A. C. L., Ativismo Negr@: entrecruzando epistemologias feministas nas trajetórias de mulheres negras e religiosas. ODEERE, v. 6, n. 01, jan./jun., p. 38-66, 2021. https://doi.org/10.22481/odeere.v6i01.8734

campo religioso, os femininos representados pelas mitologias das labás abrem um leque de possibilidade em relação à diversidade dentro das experiências femininas, acionadas por noções de poder, autonomia, liderança, maternidade, sensualidade e performances de sexualidades, afastadas das limitações impostas quanto as funções reprodutivas. Por exemplo, as mitologias sagradas de quatro labás 20 do candomblé de origem lorubá estabeleceram outras possibilidades aos femininos além do arquétipo de progenitora, em que cada uma possui um poder específico no Brasil, pois "são apresentadas como mães, amantes e esposas, envolvendo diversos aspectos da sexualidade feminina"21.

Desse modo, essas abordagens localizadas no campo do feminismo negro e decolonial permitem verificar que as discussões no tocante ao protagonismo de mulheres negras e a pertinência da mitologia sobre as labás também ganharam destaque dentro das produções científicas contra-hegemônicas, especialmente com a produção do feminismo e do Ativismo Negr@ pensado a partir do candomblé, ajudando a sistematizar no campo epistemológico noções de autonomia feminina, poder, liderança e até as sexualidades, no dinamismo situado em diferentes ensinamentos dentro das comunidades dos cultos afro-brasileiros.

Por compreendermos a importância política e o peso teórico dessas produções, cabe levantar o questionamento a respeito de como os corpos e sexualidades podem ser administrados com relação às vivências concretas de mulheres negras inseridas nesta religiosidade, com base na relação entre as mitologias e as dinâmicas da vida social. Acerca disto, partimos das considerações de que tradições míticas não estão isoladas do mundo social onde produções discursivas são empreendidas com relação ao gênero e as sexualidades²2, e que são perpassadas por normativas hegemônicas que estabelecem barreiras com relação aos trânsitos entre desejos sexuais e performances dissidentes da moralidade sexista, ao empreender processos educativos/regulatórios a respeito

negras e a cultura midiática. Tese de Doutorado (Doutorado em Comunicação) Universidade Federal do Rio de Janeiro, Rio de Janeiro, 2007; dentre outras pesquisas.

20Utilizamos como referências às orixás: lemanjá, lansã, Oxum e Obá.

21ZENICOLA, Denise Mancebo. Performance e ritual: a dança das labás no Xirê. Rio de Janeiro: Mauad Editora, 2014, (p. 37).

${ }^{22} \mathrm{AMIM}$, Valéria. Candomblé e mitologia: a sexualidade no rito, no corpo e na dança. Revista Língua \& Literatura, v. 35, 2018, (p. 119-130). 
Lopes, M. L., Pacheco, A. C. L., Ativismo Negr@: entrecruzando epistemologias feministas nas trajetórias de mulheres negras e religiosas. ODEERE, v. 6, n. 01, jan./jun., p. 38-66, 2021. https://doi.org/10.22481/odeere.v6i01.8734

dos $\operatorname{corpos}^{23}$. Considerando as sociedades ocidentais, o sexo é um tabu permeado por interditos e por diferentes mecanismos de saber e poder através de diferentes tecnologias biopolíticas que agem estabelecendo normativas quanto aos desejos 24 . E nesse sentido, cabe interrogar no tocante aos limites e/ou possibilidades dentro da intersecção composta por religiosidade e sexualidade, quanto as práticas das mulheres negras no candomblé.

Tomando como recorte a dimensão das experiências de mulheres negras no candomblé, cabe questionar: De que modo o universo de significação presente nas mitologias sobre as Orixás femininas influenciam o modo com as praticantes desta religiosidade - sejam elas Filhas de santos, Ekedis, Ebomis, Sacerdotisas mobilizam conceitos e/ou representações relacionadas ao corpo e suas intersecções, a partir das experiências relacionadas ao gênero? E de que modo as referências baseadas nas Orixás são acionadas através da religiosidade, instigando vivências com o corpo e a sexualidade? Essas são questões que buscaremos desenvolver ao longo deste artigo, nos limitando as discussões levantadas a partir da trajetória de Belmira.

Dialogando com outro campo de produções teóricas, a teologia feminista (TF) se baseia nas diferentes experiências femininas para denunciar os processos de subalternização e violências engendrados por instituições religiosas patriarcais. Os estudos feministas em torno da categoria gênero serviram como base para o surgimento de um feminismo cristão e como influência para a elaboração de um campo de análise que vem ganhando força desde o século XX25, e que se dedica a tratar das relações de poder e dos conflitos de gênero dentro de instituições religiosas ${ }^{26}$. Essa teologia inicialmente teve como cenário países europeus e os Estados Unidos, vindo a se organizar entre 1970 e 1980 na América Latina, Ásia e África em um período de forte reflexão feministas no que tange as demandas de mulheres, dos debates acerca do gênero e das críticas religiosas como instrumento

\footnotetext{
${ }^{23}$ LOURO, Gaucira Lopes. Pedagogias da sexualidade. In: da sexualidade. Belo Horizonte: Autêntica Editora, 2019, (p. 9-42).

24FOUCAULT, Michel. História da sexualidade I: a vontade de saber. São Paulo: Editora Paz e Terra, 2015.

25 Importante pontuar que contestações a respeito do campo religioso cristão já vinham ocorrendo antes mesmo do século XX. Anteriormente, nomes como o de Juana Inés de La Cruz e Elisabeth Cady Stanton foram importantes para considerar a insurgência de vozes femininas que se posicionavam contra a ordem social estabelecida pelo masculino sobre as religiões cristãs.

${ }^{26}$ GEBARA, Ivone. O que é teologia feminista. São Paulo: Brasiliense, 2017.
} 
Lopes, M. L., Pacheco, A. C. L., Ativismo Negr@: entrecruzando epistemologias feministas nas trajetórias de mulheres negras e religiosas. ODEERE, v. 6, n. 01, jan./jun., p. 38-66, 2021. https://doi.org/10.22481/odeere.v6i01.8734

de dominação colonial de povos ${ }^{27}$, tendo como ponto em comum a tentativa de evidenciar as desigualdades de gênero dentro da constituição de discursos e de símbolos religiosos.

No tensionamento entre narrativas estabelecido a partir da produção teológica a respeito da Igreja Católica, os direitos sexuais e reprodutivos se tornaram uma das principais bandeiras reivindicadas pela teologia feminista católica, mediante a noção de cidadania em relação a garantia da amplitude dos direitos humanos de mulheres frente a autonomia dos seus corpos e sexualidades 28 . Por exemplo, mulheres pretas, pardas, amarelas e indígenas e de classe popular são as mais violentadas pela incorrência de abortos clandestinos no Brasil e que em muitos casos as condenam a morte e/ou a criminalização jurídica por parte do Estado29, sendo que muitas delas compartilham de religiosidades de matriz cristã.

Desta forma, estas produções emergem como contradiscurso que tensiona através da ação teológica feminista as engenharias: "anti-corpo, anti-sexo e antimulher" presentes nas tradições do catolicismo, em que um dos principais pontos de discussão é o modo problemático com que esta instituição lida com os corpos das mulheres. Por conseguinte, a teologia feminista católica parte do objetivo de reafirmar experiências femininas positivas com relação as sexualidades, em garantia de autonomia e da equidade entre os gêneros dentro e fora de instituições religiosas.

\footnotetext{
27TABORDA, Francisco S. j. Feminismo e teologia feminista no primeiro mundo: breve panorâmica para uma primeira informação. Perspectiva Teológica, Belo Horizonte, v. 22, 1990, (p. $311-337$ ).

${ }^{28}$ Como exemplo, a organização Católicas pelo Direito de Decidir tem representado a articulação do movimento feminista com teólogas feministas e parte da comunidade católica de doze países da América Latina a partir da década de 1990, dentre eles o Brasil, ao assumirem a defesa dos direitos sexuais e reprodutivos das mulheres. Alertando que o conservadorismo religioso tem impedido o avanço dos direitos humanos das mulheres, mediante a percepção de relações estreitas entre política e igreja/religião que desrespeitam os princípios da laicidade do Estado.

${ }^{29}$ A Pesquisa Nacional de Aborto em 2016, demostrou que uma a cada cinco mulheres brasileiras até os 40 anos já realizou pelo menos um aborto clandestino ao longo da vida. No entanto, as mulheres de baixa renda e com menor escolaridade representam números expressivos se comparado com as mulheres com poder aquisitivo, são as mulheres pretas, pardas, amarelas e indígenas as que mais sofrem com as complicações causadas pelo aborto realizado na ilegalidade, reforçando as considerações de que o recorte étnico e racial complexifica a realidade dos casos de obtido ou de penalização jurídica por parte do Estado. Considerando essa realidade, a criminalização do aborto tem contribuído para que o Estado e instituições religiosas reforcem violências causadas pela desigualdade social, recortadas principalmente com relação o gênero e a raça, investindo diretamente para a reprodução de estigmas sociais a respeito da mulher que aborta clandestinamente. DINIZ, Debora, et al. Pesquisa nacional de aborto 2016. Ciência \& Saúde Coletiva, v. 22, 2017, (p. 653-660).
} 
Lopes, M. L., Pacheco, A. C. L., Ativismo Negr@: entrecruzando epistemologias feministas nas trajetórias de mulheres negras e religiosas. ODEERE, v. 6, n. 01, jan./jun., p. 38-66, 2021. https://doi.org/10.22481/odeere.v6i01.8734

Não obstante, é necessário considerar as limitações em afunilar as questões ligadas à autonomia e aos direitos reprodutivos tomando como base especialmente a dimensão do direito ao aborto - ainda que esta seja uma discussão necessária relacionada a saúde pública. É importante considerar o fato de que ao ter elencado o direito ao aborto como uma das pautas principais para reivindicar a garantia dos Direitos Humanos das mulheres e a laicidade do Estado, algumas produções teológicas feministas católicas focaram a discussão no que concerne a problemática institucional do catolicismo com os corpos femininos e o peso psicológico da religiosidade no tocante às mulheres, mas acabaram deixando de lado outras dimensões relacionadas aos direitos sexuais e reprodutivos. Dentro desta seara podem emergir diferentes questões, como por exemplo, as diferentes possibilidades de vivenciar o prazer e os desejos sexuais, além das opções pela não reprodução e como estas são administradas por mulheres que vivenciam o catolicismo, sendo que a prerrogativa dogmática ainda associa o sexo apenas a fins reprodutivos.

Nesse sentido, um dos aspectos que emergiriam na nossa análise da trajetória de Madalena foi a dimensão dos descompassos entre os valores morais e dogmáticos instituídos pela instituição católica e o modo como ela vivenciava a religiosidade. No caso dessa colaboradora passamos a questionar: Como as diferentes formas de vivenciar a religiosidade católica afetavam a relação dela com seu corpo e seus desejos, devido aos conflitos circunstanciados no estabelecimento de seus vínculos afetivo-sexuais? Tomando a interrogação a partir deste ponto, analisamos quais eram os conceitos mobilizados por Madalena quando ela pensava em seu corpo e sexualidade, e como era impactada psicologicamente pela forma como vivenciava a religiosidade.

Desta maneira, as dimensões do Ativismo Negr@, do feminismo negro e decolonial e a teologia feminista abordadas aqui são diferentes campos que apresentam boas contribuições a respeito das intersecções entre religiosidades e gênero, pois informam os diferentes tipos de representações no tocante ao feminino, e que nos ajudaram a analisar as complexidades por traz das narrativas de Madalena e Belmira no que se refere as dimensões voltadas para o corpo. Em se tratando das discussões no que diz respeito à sexualidade feminina pautada dentro da heterossexualidade, observamos possibilidades e limites teóricos, 
Lopes, M. L., Pacheco, A. C. L., Ativismo Negr@: entrecruzando epistemologias feministas nas trajetórias de mulheres negras e religiosas. ODEERE, v. 6, n. 01, jan./jun., p. 38-66, 2021. https://doi.org/10.22481/odeere.v6i01.8734

cabendo a necessidade de ampliar as discussões dentro da intersecção entre religiosidade e sexualidade nos dois contextos destacados, no sentido de percebermos práticas e representações elaboradas concernentes aos corpos e desejos a partir do que narram as mulheres negras da pesquisa, a respeito de como produziam, recriavam e/ou subverteram os processos normativos dentro das instituições religiosas.

Para alcançar tal objetivo, entrecruzamos estas diferentes epistemologias feministas no sentido de analisarmos as trajetórias de Madalena e Belmira e verificarmos como a religiosidade tem sido um elemento essencial de constituição das identidades, articuladas com os diversos marcadores interseccionais. Observado a historiografia da sociedade sul baiana a partir de suas heranças coronelistas e da profunda desigualdade social ainda vigente, constatamos que gênero, raça e classe demandaram intersecções importantes nas trajetórias sociais, como várias pesquisas no campo de estudos acerca das mulheres negras no Brasil já haviam sinalizado 30 , pois informaram no tocante ao lugar de produção da marginalidade de mulheres racializadas.

No que pesam dados recolhidos da historiografia do sul da Bahia e em obras memorialistas de Canavieiras, foi possível perceber como os corpos principalmente das mulheres negras aparecem estereotipados como "ninfas negras", retratadas a partir do aspecto hipersexualizado que denotam a noção de objeto sexual para o usufruto dos ricos fazendeiros da região31, julgadas como portadoras de "condutas imoderadas", "sexualidade desenfreadas", "iniciadoras sexuais", além da criminalização de suas etnicidades e religiosidades 32 , sendo postas como corpos para o trabalho e ao serviço.

Neste caso, a interseccionalidade, em sua utilização teórico-metodológica,

\footnotetext{
${ }^{30}$ BAIRROS, Luiza. Nossos feminismos revisitados. Revista Estudos Feministas, v. 3, 1995, (p. 458-463); CARNEIRO, Sueli. A batalha de Durban. Revista Estudos Feministas, v. 10, 2002, (p. 209-214); PACHECO, Ana Cláudia Lemos. Mulher negra: afetividade e solidão. Salvador: Edufba, 2013.

${ }^{31}$ Vide: COSTA, Alcides. Canavieiras: sua história e sua gente (lendas e festas). Itabuna, Ba: Via Litterarum, 2014.

32SANTOS, Cristiane Batista da Silva. Entre o fim do império da farinha e início da república do cacau: negros em festas, sociabilidades e racialização no sul da Bahia (1870-1919). Tese de Doutorado. (Doutorado em Estudos Étnicos e Africanos), Universidade Federal da Bahia, Salvador-Bahia, 2015; SANTOS, Cristiane Batista da S. "Um vivo demônio capaz de sugerir as maiores desordens": mulheres bem e mal procedidas em pecados no sul da capitania da Bahia. ODEERE: Revista do Programa de Pós-Graduação em Relações Étnicas e Contemporaneidade, v. 4, 2019, (p. 68-100).
} 
Lopes, M. L., Pacheco, A. C. L., Ativismo Negr@: entrecruzando epistemologias feministas nas trajetórias de mulheres negras e religiosas. ODEERE, v. 6, n. 01, jan./jun., p. 38-66, 2021. https://doi.org/10.22481/odeere.v6i01.8734

foi uma ferramenta de análise e investigação utilizada na pesquisa, que permite verificar as articulações indissociáveis entre opressões que operam sobre grupos marginalizados ${ }^{33}$. Através do uso desta ferramenta percebeu-se que as trajetórias de Madalena e Belmira informavam a respeito de diferentes alternativas de resistência para garantir a subsistência em Canavieiras, em que a religiosidade emergiu como elemento essencial para os modos de experienciar o gênero e a sexualidade. Nessa perspectiva, a interseccionalidade nos atentou para a sensibilidade analítica, para que impeça redundâncias frente às identidades ${ }^{34}$, compreendendo os corpos a partir das "avenidas identitárias" que os constituem, de modo que cabe considerar "quais condições estruturais transpassam os corpos, quais posicionalidades, reorientam significados subjetivos desses corpos, por serem experiências modeladas por e durante a interação das estruturas" 35 .

À vista disso, nossa encruzilhada parte principalmente do contexto em que historicamente estão inseridas as mulheres negras sul baianas, compreendendo os processos de colonialidade do gênero ${ }^{36}$ como um processo de desumanização dos corpos mediante as articulações de raça/classe/etnia/sexualidade, que pesam principalmente para as mulheres racializadas, suprimidas em grande parte das abordagens que tratam de gênero, construídas a partir do lugar de privilégio branco e ocidental. Pois diferente da realidade das mulheres racializadas, o corpo da mulher branca, ainda que violado pelo sistema cis-hétero-patriarcal e cristão,

\footnotetext{
${ }^{33}$ CRENSHAW, Kimberlé. Documento para o encontro de especialistas em aspectos da discriminação racial relativos ao gênero. Revista Estudos Feministas, v. 10, 2002, (p. 171-188).

${ }^{34}$ Cabe destacar que a perspectiva interseccional é uma sensibilidade analítica fruto dos movimentos sociais e pautada por ativistas e intelectuais negras como Lélia Gonzalez, Ângela Davis, bell hooks, Alice Walker, dentre outras, tendo como marco as décadas de 1970 e 1980, que tomaram como base as análises estruturais no que concerne à sociedade capitalista de base escravagista, para verificar a reincidência do sexismo, do racismo e da opressão de classe principalmente orquestradas sobre mulheres negras. O legado destas intelectuais tem sido de fundamental importância para a compreensão de que gênero e raça não se opõem enquanto marcadores de opressão, mas que ambos estão imbricados sobre os corpos destas mulheres. Posteriormente, ao sistematizar teoricamente as reflexões no que diz respeito as interações entre marcadores de opressão, Kimberlé Crenshaw contribuiu para desenvolver o conceito de interseccionalidade no campo do direito, sobretudo a partir da década 1990, onde traduziu em termos teóricos um modelo analítico ampliado apoiado no feminismo negro, como projeto de justiça social e práxis crítica, que ajudava a observar como o tráfego das articulações entre gênero e raça produziam variadas "avenidas identitárias" especialmente acerca dos dilemas vivenciados por mulheres negras que limitavam a garantia dos direitos humanos.

${ }_{35}$ AKOTIRENE, Carla. Interseccionalidade. São Paulo: Polén, 2019, (p. 43).

${ }^{36}$ LUGONES, María. Rumo a um feminismo descolonial. Revista Estudos Feministas, v. 22, 2014, (p. $935-$ 952).
} 
Lopes, M. L., Pacheco, A. C. L., Ativismo Negr@: entrecruzando epistemologias feministas nas trajetórias de mulheres negras e religiosas. ODEERE, v. 6, n. 01, jan./jun., p. 38-66, 2021. https://doi.org/10.22481/odeere.v6i01.8734

sempre esteve na zona do privilégio marcado pela branquitude, privado, naturalizado para a demanda da afetividade e regulado para a reprodução biológica da família ${ }^{37}$. Deste modo, salientamos a importância de discutir as imbricações de religiosidades a partir do dado da colonialidade, em relação às violências provocadas pelas imbricações do racismo, sexismo e do capitalismo na constituição do cis-hetero-patriarcado cristão e ocidental, para especificar que principalmente com relação as mulheres negras e indígenas, a raça informa experiências de gênero diferenciadas e associadas às narrativas negativas e colonizadoras.

A análise das trajetórias de Belmira e Madalena, observadas por este prisma nos informaram a respeito de estratégias diferenciadas na elaboração de alternativas de resistência, também pautadas pelo modo com que se relacionam com o catolicismo e o candomblé. Uma das primeiras similaridades entre as trajetórias é que ambas são mulheres negras oriundas da classe trabalhadora e de baixa renda que atuam/atuaram em ocupações na prestação de serviços de baixa remuneração no decorrer da infância, em que a construção de teias matrifocais entre mães e filhas foram essenciais para subsistência familiar, chegando à vida adulta e a idade madura uma como trabalhadora doméstica e outro como pescadora artesanal. Dentro desta dimensão gênero e raça são marcados interseccionados que contribuíram para os processos de subalternização no tocante aos corpos destas mulheres, que fazem parte do grupo mais impactado pelas desigualdades sociais, políticas e econômicas dentro da realidade brasileira 38 .

No entanto, ainda que as dimensões do racismo articuladas com gênero e classe sejam percebidas nas encruzilhadas através de pontos similares entre as duas trajetórias, elas se diferenciam com relação as suas subjetividades, podendo considerar importante para essa compreensão, os traços diacríticos localizados em suas religiosidades.

Madalena congregava em sua narrativa a aproximação com o universo religioso judaico-cristão que interviam nos princípios morais e simbólicos, denotadas

\footnotetext{
${ }^{37}$ STOLKE, Verena. O enigma das interseções: classe," raça", sexualidade: a formação dos impérios transatlânticos do século XVI ao XIX. Revista Estudos Feministas, v. 14, 2006, (p. 15-42).

${ }^{38}$ CARNEIRO, Sueli. Racismo, sexismo e desigualdade no Brasil. São Paulo: Selo Negro, 2011.
} 
Lopes, M. L., Pacheco, A. C. L., Ativismo Negr@: entrecruzando epistemologias feministas nas trajetórias de mulheres negras e religiosas. ODEERE, v. 6, n. 01, jan./jun., p. 38-66, 2021. https://doi.org/10.22481/odeere.v6i01.8734

por normativas de como vivenciar as crenças e se portar em público como uma mulher católica, em que os modelos de representação congregavam valores monoteístas para compreender o mundo, pautadas pela divisão bem/mal, anjo/demônio. Já Belmira, trouxe para o centro das narrativas a paixão pela cultura associada ao universo da etnicidade e cultura negra de origens africanas herdadas e ressignificadas na diáspora africana no Brasil, constituída no universo de significação do candomblé e de suas vivências religiosas, políticas e sociais dentro desses campos. Tomando como base estas dimensões das trajetórias, as associações religiosas das colaboradoras apontam que diversos marcadores sociais podem contribuir para a construção da identidade étnica de cada pessoa, entre elas a religiosidade.

Sendo assim, o dado da religiosidade demarca no universo observado a diferenciação de mulheres negras em termos de suas identificações étnicas, pois o corpo é utilizado de diferentes formas como ferramenta de acesso e manutenção das práticas religiosas, onde se legitimam diferentes sentidos de ligação com elementos sacralizados que permitem a efetivação e veiculação de crenças e valores, a partir do campo da moralidade.

Além de ser um traço diacrítico para as associações étnicas, a religiosidade suscita reflexões importantes a respeito do corpo e da sexualidade de mulheres negras, em que distintas epistemologias feministas enfatizaram que são dimensões que levantam questões relevantes e necessárias dentro dos feminismos. Considerando os campos discursivos do feminismo negro e decolonial e a teologia feminista católica para tensionar o campo da religiosidade, esses diferentes campos de produção do conhecimento ajudaram a visualizar dois universos distintos de interpretações quanto ao corpo e a sexualidade, presente nas trajetórias das colaboradoras de pesquisa, contudo, coube ainda a necessidade de verificar como as interpretações singulares pautadas nas religiosidades nortearam suas visões de mundo, suas relações interpessoais, seus modos de existir e (re)existir, e protagonizar suas vidas tomando como referência os seus corpos.

\section{Percepções a respeito do corpo e da sexualidade nas trajetórias}

Analisando o catolicismo e o candomblé como dimensões importantes nas 
Lopes, M. L., Pacheco, A. C. L., Ativismo Negr@: entrecruzando epistemologias feministas nas trajetórias de mulheres negras e religiosas. ODEERE, v. 6, n. 01, jan./jun., p. 38-66, 2021. https://doi.org/10.22481/odeere.v6i01.8734

experiências religiosas de Madalena e Belmira, compreendemos como a religiosidade contribuiu para que elas elaborassem diferentes conceitos relacionados ao gênero feminino. Nesse sentido, para compreender como os corpos apareceram mobilizados para cada colaboradora, foi importante considerar que nas trajetórias analisadas a religiosidade norteou significativamente a mobilização de diferentes conceitos no que se referem as representações a respeito do que simbolizava "ser mulher", que interferiram em determinados limites da sexualidade.

Belmira mobilizou um conceito relativamente ao gênero a partir da compreensão de que mulher é "sexo forte", fazendo referência a um padrão de feminilidade que perfaz sua trajetória, pautada pela independência pessoal e autonomia feminina, principalmente com relação a parceiros afetivos. Na trajetória de Belmira, essa representação de gênero sustentava a diferenciação binária a respeito do masculino e do feminino, numa perspectiva cis-gênero e heterossexual. Para ela, a negação da existência de uma fragilidade feminina aparecia em sintonia com a conexão estabelecida dentro das cosmovisões relacionadas os/as orixás, especialmente a que rege seu orí, a labá lansã, simbolizada no universo iorubá como deusa guerreira e subversiva. lansã (Oyá) deusa do fogo e das tempestades carrega dentro da cosmologia iorubá a representação de uma labá destemida, que carrega a força e altivez da mulher que reivindica independência e é batalhadora dentro da sua realidade, mas que também carrega no corpo uma sexualidade ardente, transitante por espaços de poder, "de temperamento forte, intrépida, voluntariosa e sensual, lansã é uma deusa guerreira [...] enquanto a sociedade patriarcal não comporta a insubordinação feminina, ela é mitificada no candomblé"39.

Em vista disso, a significação presente nas mitologias sobre essa orixá instigava de modo significativo a forma como Belmira acionava este conceito de feminino pautado na noção de "sexo forte". É importante considerar que feministas negras têm sustentado que dentro desse universo mítico que carrega diferente possibilidade para o feminino, para além das binaridades bem/mal,

${ }^{39}$ CARNEIRO, Sueli; CURY, Cristiane. O poder feminino no culto aos orixás. In: NASCIMENTO, Elisa Larkin (org). Guerrerias de natureza: mulher negra, religiosidade e ambiente. São Paulo: Selo Negro, 2008, (p. 128-129). 
Lopes, M. L., Pacheco, A. C. L., Ativismo Negr@: entrecruzando epistemologias feministas nas trajetórias de mulheres negras e religiosas. ODEERE, v. 6, n. 01, jan./jun., p. 38-66, 2021. https://doi.org/10.22481/odeere.v6i01.8734

santa/pecadora, as representações a respeito das deusas negras no universo do candomblé demarcam um lugar de protagonismo feminino, que desloca o modelo de civilização moral e sexista ocidental, que sempre subordina o feminino em relação ao masculino 40 .

A partir de outra interpretação, Madalena mobilizou suas representações relacionadas ao gênero feminino a partir do acionamento da noção a respeito da mulher que possui vínculos afetivos baseados nas relações tradicionais da família heterossexual e monogâmica, sendo a figura que gesta e mantém o cuidado para com a família e o lar, ao mesmo tempo em que sentia a necessidade de manter a sabedoria e retidão cristã, na busca para alcançar um modelo de "mulher sábia que edifica o lar". Esta noção de feminilidade apareceu articulada com a representação de feminino construída pelo cristianismo, em que a mulher é figura central da manutenção dos laços familiares e do cuidado para com os entes familiares e em que sustentam hierarquias binários quanto ao gênero, demarcados na articulação entre quem cuida (a mulher) e quem gerencia a família (o homem).

Ao acionar esse conceito de "mulher sábia" que muito tolera e que tem a responsabilidade de modificar a realidade do seu lar e das relações tecidas dentro do contexto da família, mediante a compreensão construída pela mentalidade cristã de que "a mulher sábia edifica seu lar", Madalena indiretamente elencava como referência a figura de maior representação histórica de um modelo de feminino, que é a elaboração mítica e dogmática da Virgem Maria, produzida historicamente dentro da cosmologia dogmática da Igreja Católica. Esse modelo de feminino mariano e dogmático regelou às mulheres um lugar subordinado, ao mesmo tempo em que impôs sobre elas a necessidade de regulação, imaginadas como figura essencialmente tentadoras e perigosas. Estas proposições têm sido discutidas por teólogas feministas mediante considerações de que a Igreja Católica apresenta resistência em lidar com os corpos e com as sexualidades, principalmente relacionado as mulheres ${ }^{41}$. As principais denúncias feitas são

\footnotetext{
${ }^{40}$ SIQUEIRA, Lourdes. Iyami lya Agbas dinâmica da espiritualidade feminina em templos afrobaianos. Revista Estudos Feministas, v. 3, 1995, (p. 436 - 445); CARNEIRO, Sueli; CURY, Cristiane. O candomblé. In: NASCIMENTO, Elisa Larkin (org). Guerrerias de natureza: mulher negra, religiosidade e ambiente. São Paulo: Selo Negro, 2008, (p. 97-115).

${ }^{41}$ ROSADO, Maria José Nunes. Direitos, cidadania das mulheres e religião. São Paulo: Tempo social, v. 20, 2008, (p. 67-81; FURLIN, Neiva. Teologia feminista: uma voz que emerge nas margens do discurso teológico hegemônico. Rever, São Paulo, v. 11, 2011, (p. 140-164); GEBARA, Ivone. Direitos
} 
Lopes, M. L., Pacheco, A. C. L., Ativismo Negr@: entrecruzando epistemologias feministas nas trajetórias de mulheres negras e religiosas. ODEERE, v. 6, n. 01, jan./jun., p. 38-66, 2021. https://doi.org/10.22481/odeere.v6i01.8734

concernentes ao modo conflituoso com que esta instituição lida com a sexualidade feminina, bem como de sexualidades destoantes do padrão ocidental da heterossexualidade. O corpo feminino entendido como reflexo do pecado, herdeiro da maldição de Eva, precisaria então ser contido, coberto, moralizado para impedir que sua essência tentadora se manifestasse ${ }^{42}$.

Nesse sentido, os diferentes conceitos e representação de feminino mobilizados pelas colaboradoras de pesquisa norteiam o debate com relação as diferentes formas de representar o gênero, circunstanciadas pelo catolicismo e candomblé, e que complexifica a partir da religiosidade os modos de agir frente as dinâmicas do cotidiano. Cabe observar que se de um lado a representação das deusas na mitologia sobre as orixás femininas na diáspora levantam imaginários positivos relativamente ao poder e altivez feminina no universo do candomblé, em que os femininos podem ser transitantes entre as referências de mães protetoras, guerreiras, destemidas, sensuais e sexuais sem que estejam imersas ou limitadas nas normativas de gênero pautadas pelo pudor cristão. Por outro lado, o princípio de representação da "mulher sábia que edifica o lar" ainda contribui para legitimar diferentes violências sobre as mulheres, especialmente a partir da responsabilização por parte destas que ainda as culpabilizam pelos insucessos e pelas violações sofridas em âmbito doméstico e familiar43.

Paralelo a esses fatos, os corpos aparecem complexificados na trajetória dessas mulheres. O corpo narrado por Madalena apareceu diretamente tangenciado pela religiosidade católica em sua ligação com a realidade concreta e cotidiana, que passa a ser elaborado publicamente para não escandalizar e nem borrar a imagem de mulher católica praticante, que não deve destoar da figura religiosa construída dentro e fora do espaço da igreja, controlado em suas performances públicas: seja através do uso de vestimentas ou do comportamento, como formas de alcançar a idealização de uma conduta moral prescrita

sexuais, direitos reprodutivos e outros direitos: uma conversa breve para lembrar coisas importantes. In: JURKEWICZ, Regina Soares. Teologias fora do armário: teologia, gênero e diversidade sexual. Jundiaí, SP: Max Editora, 2019, (p. 56-72).

${ }^{42}$ TOMITA, Luiza E. Da exclusão a objeto de prazer: o corpo das mulheres oferece notas para uma reflexão teológica feminista. Mandrágora, v. 13, 2007, (p. 45-51).

${ }^{43}$ DELGADO, Teresa. Este corpo é meu... que dou a vocês: antropologia teológica Latina/Mente. In: ABRAHAM, SUsan; FOLEY-PROCARIO, Elena (orgs). Nas fronteiras da teologia feminista católica. Aparecida, São Paulo: Editora Santuário, 2013, (p. 39-65). 
Lopes, M. L., Pacheco, A. C. L., Ativismo Negr@: entrecruzando epistemologias feministas nas trajetórias de mulheres negras e religiosas. ODEERE, v. 6, n. 01, jan./jun., p. 38-66, 2021. https://doi.org/10.22481/odeere.v6i01.8734

relativamente a mulher católica e que recai também na moralidade sexual. É importante perceber através desse dado, que o fato dela ter optado por uma vida católica promoveu cisões em sev entendimento com relação as roupas ideais para se vestir, mediante a separação entre "roupa composta" para sair e "roupa para dentro de casa".

As roupas são acionadas como código moral, mediadoras da dinâmica de compostura da mulher católica. Dentro desses códigos, a necessidade de cobrir o corpo no espaço público da rua e da igreja são formas de introjeção da lógica em relação ao corpo feminino entendido como veículo para a sedução, e principalmente, para o pecado. No que diz respeito a esta questão, a noção de "corpos femininos sitiados" ajuda a pensar como as políticas de controle do corpo e da mente sustentadas pela moral religiosa e sexual católica têm favorecido para que as instituições religiosas cristãs legislem sobre as mulheres e seus desejos, de modo que as reproduções de uma moralidade cristã por parte delas podem se tornar aparatos naturalizados de acesso a fé e a devoção ${ }^{44}$.

Por isso, umas das formas de Madalena executar essa tentativa de ser uma "mulher sábia" dentro dos preceitos morais e religiosos católico é através do uso do corpo, fugindo do estigma associado ao corpo da "mulher pública", julgada pelo estereótipo de "má reputação" e apontada por outras pessoas, que vão contra a imagem de mulher católica. Contudo, dentro dessas dimensões é importante considerar que é justamente a dimensão da sexualidade que borra os limites que Madalena se coloca mediante aos moldes cristãos.

Quando Madalena passou a seguir de fato a religiosidade católica já estava casada e mãe de dois filhos e nesse contexto, sua sexualidade estava alocada as vivências no âmbito familiar tecidas nas relações sexuais e afetivas com o antigo companheiro. No entanto, em meio as situações de conflitos no relacionamento o pacto da monogamia no relacionamento foi burlado por ela quando incorreu na traição do antigo companheiro. Pela tradição dogmática que segue, Madalena interpretou essa situação como uma fraqueza pessoal resultado do fato de ainda

${ }^{44}$ GEBARA, Ivone. Sofrimento de mulheres e religião. Webinar apresentado por Ivone Gebara, Debora Diniz e Lusmaria Campos Garcia. 28 de agosto, 2020. 1 vídeo (1h 29min 22seg. Publicado pelo canal Anis - Instituto de Bioética. Disponível em: https://www.youtube.com/watch? v=lLfiyqZdA9E. Acessado em: 28/08/20. 
Lopes, M. L., Pacheco, A. C. L., Ativismo Negr@: entrecruzando epistemologias feministas nas trajetórias de mulheres negras e religiosas. ODEERE, v. 6, n. 01, jan./jun., p. 38-66, 2021. https://doi.org/10.22481/odeere.v6i01.8734

não ter alcançado a condição de fortalecimento na fé e associou o fato as tentações por parte de "satanás". A figura do "mal", interpretada pela criação cristã de satanás, apareceu relacionada à fraqueza, sendo uma das responsáveis pelo rompimento da informante com essa relação conflituosa. Ter deixado "satanás" vencer por falta de sabedoria na fé, significava para ela conviver com o peso da culpa e do arrependimento.

Essa crença na figura de satanás é acionada por diferentes seguimentos de religiosidades cristãs, para justificar a fraqueza na fé e a incorrência em atos considerados falhos e pecaminosos. Nesse sentido, os desvios de conduta são justificados pela presença de satanás, ao mesmo tempo em que a correção da falha é justificada como possível de ser alcançada a partir do fortalecimento dos laços com as instituições religiosas, instituindo-as como as grandes corretoras das personalidades tidas como desviantes de seus membros 45 .

E nesse sentido, o fato de ter vivenciado um contato esporádico que retirou o desejo sexual dos domínios do casamento faz com que ela carregasse a culpa da permissividade com relação ao pecado da luxúria. Dessa forma, na sua vivência efetiva da sexualidade Madalena acabava burlando os limites de retidão pautada pelo catolicismo, em que os desejos e práticas sexuais deveriam ser apreendidos no espaço do matrimônio. Sendo assim, ainda que preservasse os valores cristãos e possuísse idealizações quanto ao gênero feminino a partir da dogmática católica, em sua condição de humanidade ela transpunha os conceitos rigidamente sacralizados em relação a ser mulher católica.

Contudo, ela alimentava o inconformismo de não ter conseguido alcançar a postura de uma "mulher sábia", e era esse ponto da questão em que a religiosidade pesava psicologicamente sobre ela, na medida em que reagia as diferentes situações que havia vivenciado ao longo da vida, julgando possuir uma trajetória associada à noção de "viver em pecado". Esta noção influenciava a relação de Madalena com seu corpo e seus desejos, julgadas a partir do estabelecimento de vínculos afetivo-sexuais. Desse modo, esta colaboradora aparentava estar diretamente afetada pelos descompassos entre os valores morais e dogmáticos instituídos pela instituição e o modo como ela vivenciava a

${ }^{45}$ MACHADO, Maria das Dores Campos. Corpo e Moralidade Sexual em Grupos Religiosos. Estudos Feministas, n. 1, 1995, (p. 7-27). 
Lopes, M. L., Pacheco, A. C. L., Ativismo Negr@: entrecruzando epistemologias feministas nas trajetórias de mulheres negras e religiosas. ODEERE, v. 6, n. 01, jan./jun., p. 38-66, 2021. https://doi.org/10.22481/odeere.v6i01.8734

religiosidade, a partir desse lugar de conflito entre o que idealiza viver como mulher católica (mulher sábia) e o que conseguia efetivar na sua prática (viver em pecado).

Já Belmira, articulava diferentes conceitos acerca do corpo, que apareceram em consonância com suas vivências pensando-o como instrumento de cultuação, cuidado e conexão com as divindades, em que o corpo se constituía para ela como uma categoria forte nas tradições de origem africanas que escolheu vivenciar dentro do candomblé, em que os cuidados relacionados a ele seguem premissas envoltas de sentidos e simbolismos, que carrega uma energia vital (axé). O axé, na crença iorubá é uma energia divina e intocável, dissipada por Olorum ' e que produz o crescimento. O axé é poder que transmite energia divina. Cuidar do axé significa $\circ$ prevalecimento ritual que lida em comunhão os adeptos da religiosidade com as divindades e é distribuído sobre as pessoas e com diferentes elementos da natureza, com os animais etc., o que as torna elementos sagrados ${ }^{46}$.

O axé precisa ser cuidado, especialmente em relação ao contato corporal e sexual com outros corpos, pois são tipos de contato que carregam poluição para quem cultua divindades. No tocante aos perigos relacionados à polvição no candomblé, as "dimensões existenciais de "corpo sujo" e de "corpo limpo" são enunciadas pelo povo-de-santo para indicar estados negativos ou positivos do ponto de vista espiritual, energético e existencial". No contexto de pessoas iniciadas em comunidades de terreiro, diferentes situações podem favorecer 0 prevalecimento de corpos limpos ou sujos, a depender dos cuidados dispendidos por cada um, pois essas sujeiras/poluições podem ser tanto o contato com outras pessoas ou com outros elementos, como por exemplo interdições alimentares (chamadas de quizilas) ${ }^{47}$.

Nesse sentido, o conceito de "corpo limpo" foi mobilizado por Belmira para associar seu próprio corpo como templo de cultuação aos orixás, para fazer referência ao cargo que recebeu após sua iniciação religiosa, sendo este a função de Ekedi, e que elencou cisões importantes a respeito de como vivenciava sua

46KILEUY, Odé; OXAGUIÃ, Vera. O candomblé bem explicado: nações bantu, iorubá e fon. Rio de Janeiro: Pallas Editora, 2009.

${ }^{47} \mathrm{BASSI}$, Francesca. Transitando no limiar: processos identitários e perigos de polvição no candomblé. Revista Relegens Thréskeia, v. 5, 2016, (p. 60-83). 
Lopes, M. L., Pacheco, A. C. L., Ativismo Negr@: entrecruzando epistemologias feministas nas trajetórias de mulheres negras e religiosas. ODEERE, v. 6, n. 01, jan./jun., p. 38-66, 2021.

sexualidade. Esse é um cargo da hierarquia no candomblé correspondente a quem cuida "dos orixás e do físico dos filhos de santo, dando-lhe toda a assistência durante a incorporação"48.

Belmira ressignificou o modo como passou a vivenciar a sexualidade após iniciação no candomblé. Nesse caso, Belmira ressignificou os próprios preceitos religiosos do candomblé, que por mais que existam questões relacionadas aos resguardos temporários, não estabelece o celibato como norma para os iniciados. Esse recurso tomado a partir da iniciação religiosa, levou Belmira a reconfigurar o modo como lidava com o corpo e os prazeres sexuais, utilizando como recurso a masturbação como forma de realização do próprio desejo, em que o prazer não foi extinto e nem recusados de serem sentidos. Nesse sentido, seu corpo sexuado passava a optar pelo auto prazer, como recurso para manter-se "limpo" e sustentar seu afastamento dos conflitos no campo afetivo, com relação as suas desilusões com parceiros afetivos e as frustações provocadas por estes ao longo de sua trajetória.

Consequentemente, para Belmira as mudanças tomadas no campo da sexualidade sustentaram sua premissa de autonomia feminina com relação a parceiros, a partir da ressignificação das noções religiosas a respeito do "corpo limpo" a partir da associação feita com ela com o celibato.

Dessa forma, o modo como Madalena e Belmira passaram a lidar com seus corpos e sexualidades a partir do dado religioso estabeleceram fronteiras expressas nos modos de leituras e de mobilização de conceitos e representações relativamente ao gênero. Belmira mobilizou os sentidos com relação ao seu corpo como templo de cultuação aos orixás e que carrega uma energia vital (axé) que precisa ser cuidada, especialmente em relação ao contato corporal e sexual com outros corpos, que coadunam também com as frustações no campo afetivo. Madalena acionou a representação de um corpo adepto a necessidade de ser contido aos aspectos comportamentais e de vestimentas com o intuito de não escandalizar a imagem de uma mulher católica, em que a sexualidade aparece direcionada ao espaço da família, ainda que tenha burlado os limites impostos da monogamia e do matrimônio reconhecido pela igreja e que por essas questões

${ }^{48}$ CARNEIRO, Sueli; CURY, Cristiane. O candomblé. In: NASCIMENTO, Elisa Larkin (org). Guerreiras de natureza: mulher negra, religiosidade e ambiente. São Paulo: Selo Negro, 2008, (p. 134). 
Lopes, M. L., Pacheco, A. C. L., Ativismo Negr@: entrecruzando epistemologias feministas nas trajetórias de mulheres negras e religiosas. ODEERE, v. 6, n. 01, jan./jun., p. 38-66, 2021. https://doi.org/10.22481/odeere.v6i01.8734

viva em conflito pessoal.

No tocante a essa dimensão da heterossexualidade e dos conflitos no campo afetivo, a sexualidade também apareceu mobilizada em relação a diferentes sentidos por parte das colaboradoras. Os prazeres sexuais alocados no corpo apareceram na narrativa de Madalena, pautados dentro de relações sempre referentes a parceiros, seja nas duas relações que já vivenciou ou no dado da traição, problematizada negativamente por ela. Belmira ressignificou a relação com o próprio desejo através do prazer propiciado pela masturbação, após sua iniciação e decisão por manter o celibato, com intuito de controlar racionalmente o não envolvimento sexual e afetivo com parceiros.

\section{CONSIDERAÇÕES}

Percebemos ao longo desse artigo que as religiosidades observadas estruturavam diferentes formas de representar o gênero, que em distintos aspectos foram acionadas nas vivências das colaboradoras de pesquisa. De um lado percebeu-se a elaboração de um modelo de "mulher sábia" pautado na referência mariana contida na cosmologia católica de tradição judaico-cristã. Neste aspecto, a teologia feminista católica nos ajuda a pensar com relação ao contexto católico como historicamente problemático para o feminino, na medida em que secundarizou institucionalmente as mulheres e estigmatizou seus desejos e vontades para regular suas sexualidades, atribuindo como destino as dimensões do cuidado e da reprodução biológica como uma norma hetero-compulsória ${ }^{49}$.

Por outro lado, o candomblé, em suas diferentes variações, congrega representações diversificadas do gênero e suas performances de feminilidades 50 . Nesse contexto, a pesquisa evidenciou os sentidos atribuídos a lansã como deusa guerreira, indomável como o vento, altiva e dona de desejos insubmissos que não se rende ao controle e aos domínios externos, dando sentido as referências em relação a autonomia também relacionada aos prazeres sexuais e ao celibato.

As cosmologias sobre as labás têm orientado o protagonismo político das mulheres negras brasileiras ao longo dos séculos e no caso da ligação o Movimento

\footnotetext{
${ }^{49}$ BUTLER, Judith P. Problemas de Gênero: feminismo e subversão da identidade. Rio de Janeiro: Civilização Brasileira, 2013.

${ }^{50}$ CONCEIÇÃO, Joanice. Irmandade da Boa Morte e Culto de Babá Egum: Masculinidades, Feminilidades e Performances Negras. Jundiaí: Paco Editorial, 2017.
} 
Lopes, M. L., Pacheco, A. C. L., Ativismo Negr@: entrecruzando epistemologias feministas nas trajetórias de mulheres negras e religiosas. ODEERE, v. 6, n. 01, jan./jun., p. 38-66, 2021. https://doi.org/10.22481/odeere.v6i01.8734

de Mulheres Negras tem sido um espaço importante de reelaboração dos significados presente nas religiões de matriz africana, sobretudo por meio da consolidação das organizações não só a partir da vertente religiosa, mas também o aspecto político. Principalmente, no que diz respeito a busca por garantir a sobrevivência étnica afro-diaspórica frente aos processos de apagamentos e de racismos religiosos que vêm sofrendo ao longo da história. Para muitas destas mulheres presentes nesse Ativismo negr@ têm sido atribuídos o título de lalodês ${ }^{51}$, em analogia a esfera ritual acionadas relativamente as labás Oxum e Nanã, por suas ações de confronto e busca por equidade e por justiça social, sendo agentes essenciais para a valorização da ancestralidade negra a partir da reelaboração dos significados atribuídos relativamente as Orixás femininas.

Dessa forma, representações em relação ao feminino presentes nesses dois universos insurgiram relacionadas as trajetórias de Madalena e Belmira, a partir dos diferentes lugares religiosos de onde partem suas experiências, não como cópias regulares de um padrão fixado, mas como referências complexificadas pelas inconstâncias das vivências, atravessadas pelo dinamismo das encruzilhadas de cada uma dessas mulheres. Para estas, o corpo foi utilizado como ferramenta de acesso e manutenção das religiosidades, como algo não apenas secundário relacionado, mas elemento principal de veiculação de práticas: pois comungam, confessam, jejuam, oram, são banhados por ervas sagradas, se paramentam para cuidar de orixás e que legitimam diferentes sentidos de ligação com elementos sacralizados. Para Madalena e Belmira, os corpos também são veículos de acesso à comunidade religiosa, para efetivação e veiculação de crenças e valores que permeiam o campo da moralidade em diferentes sentidos, principalmente o aspecto de regulações através das vestimentas.

Nesse sentido, foi possível concluir que a religiosidade pode ser um marcador de diferenciação e de edificação de interditos sobre o feminino ao estabelecer "avenidas identitárias" entre grupos, pois incide consideravelmente nas representações simbólicas a respeito do gênero e suas intersecções, que mulheres católicas e candomblecistas têm como referência, sendo que interferem

\footnotetext{
51WERNECK, Jurema Pinto. Samba segundo as ialodês: mulheres negras e a cultura midiática. Tese de Doutorado (Doutorado em Comunicação) Universidade Federal do Rio de Janeiro, Rio de Janeiro, 2007.
} 
Lopes, M. L., Pacheco, A. C. L., Ativismo Negr@: entrecruzando epistemologias feministas nas trajetórias de mulheres negras e religiosas. ODEERE, v. 6, n. 01, jan./jun., p. 38-66, 2021. https://doi.org/10.22481/odeere.v6i01.8734

significativamente em suas interpretações singulares que nortearam visões de mundo, incidindo em intervenções a respeito de diferentes relações podem ser estabelecidas com os corpos e sexualidades, distintamente. A relação desse dado com o Ativismo negr@, a partir do feminismo negro e da teologia feminista informa que a religiosidade, articulada com outros marcadores, têm sido cruciais para discutir a respeito de mulheres negras, sobretudo quando se verifica o modo como tem-se acionado a produção de subjetividades e a ressignificação de jornadas a partir do campo religioso.

\section{REFERÊNCIAS:}

AKOTIRENE, Carla. Interseccionalidade. São Paulo: Polén, 2019.

AMIM, Valéria. Candomblé e mitologia: a sexualidade no rito, no corpo e na dança. Revista Língua \& Literatura, v. 35, 2018, (p. 119-130).

AUGUSTO, Geri. Transnacionalismo negro: a encruzilhada de amefrican@s. Revista da FAEEBA - Educação e Contemporaneidade, v. 25, 2016, (p. 25-38).

BAIRROS, Luiza. Nossos feminismos revisitados. Revista Estudos Feministas, v. 3,1995, (p. 458-463).

BASSI, Francesca. Transitando no limiar: processos identitários e perigos de polvição no candomblé. Revista Relegens Thréskeia, v. 5, 2016, (p. 60-83).

BERNARDO, Teresinha. Negras, mulheres e mães: lembranças de Olga de Alaketu. São Paulo: Arole Cultural, 2019.

BUTLER, Judith P. Problemas de Gênero: feminismo e subversão da identidade. Rio de Janeiro: Civilização Brasileira, 2013.

CARNEIRO, Sueli. A batalha de Durban. Revista Estudos Feministas, v. 10, 2002, (p. 209-214).

CARNEIRO, Sueli. Racismo, sexismo e desigualdade no Brasil. São Paulo: Selo Negro, 2011.

CARNEIRO, Sueli; CURY, Cristiane. O candomblé. In: NASCIMENTO, Elisa Larkin (org). Guerrerias de natureza: mulher negra, religiosidade e ambiente. São Paulo: Selo Negro, 2008, (p. 97-115).

CARNEIRO, Sueli; CURY, Cristiane. O poder feminino no culto aos orixás. In: NASCIMENTO, Elisa Larkin (org). Guerrerias de natureza: mulher negra, religiosidade e ambiente. São Paulo: Selo Negro, 2008, (p. 128-129). 
Lopes, M. L., Pacheco, A. C. L., Ativismo Negr@: entrecruzando epistemologias feministas nas trajetórias de mulheres negras e religiosas. ODEERE, v. 6, n. 01, jan./jun., p. 38-66, 2021. https://doi.org/10.22481/odeere.v6i01.8734

COLLINS, Patricia Hill. Aprendendo com a outsider within: a significação sociológica do pensamento feminista negro. Sociedade e Estado, v. 31, 2016, (p. 99-127).

CONCEIÇÃO, Joanice. Irmandade da Boa Morte e Culto de Babá Egum: Masculinidades, Feminilidades e Performances Negras. Jundiaí: Paco Editorial, 2017.

COSTA, Alcides. Canavieiras: sua história e sua gente (lendas e festas). Itabuna, Ba: Via Litterarum, 2014.

CRENSHAW, Kimberlé. Documento para o encontro de especialistas em aspectos da discriminação racial relativos ao gênero. Revista Estudos Feministas, v. 10, 2002, (p. 171-188).

DELGADO, Teresa. Este corpo é meu... que dou a vocês: antropologia teológica Latina/Mente. In: ABRAHAM, Susan; FOLEY-PROCARIO, Elena (orgs). Nas fronteiras da teologia feminista católica. Aparecida, São Paulo: Editora Santuário, 2013, (p. 39-65).

DINIZ, Debora, et al. Pesquisa nacional de aborto 2016. Ciência \& Saúde Coletiva, v. 22, 2017, (p. 653-660).

FOUCAULT, Michel. História da sexualidade l: a vontade de saber. São Paulo: Editora Paz e Terra, 2015.

FURLIN, Neiva. Teologia feminista: uma voz que emerge nas margens do discurso teológico hegemônico. Rever, São Paulo, v. 11, 2011, (p. 140-164).

GEBARA, Ivone. Direitos sexuais, direitos reprodutivos e outros direitos: uma conversa breve para lembrar coisas importantes. In: JURKEWICZ, Regina Soares. Teologias fora do armário: teologia, gênero e diversidade sexual. Jundiaí, SP: Max Editora, 2019, (p. 56-72).

GEBARA, Ivone. O que é teologia feminista. São Paulo: Brasiliense, 2017.

GEBARA, Ivone. Sofrimento de mulheres e religião. Webinar apresentado por Ivone Gebara, Debora Diniz e Lusmaria Campos Garcia. 28 de agosto, 2020. 1 vídeo (1h 29 min 22seg. Publicado pelo canal Anis - Instituto de Bioética. Disponível em: https://www.youtube.com/watch?v=ILfiyqZdA9E. Acessado em: 28/08/20.

GEERTZ, Clifford. A religião como sistema cultural. In A interpretação das culturas. Rio de Janeiro: LTC, 2008, (p. 65-91).

GOMES, Nilma Lino. O movimento negro educador: saberes construídos nas lutas por emancipação. Petrópolis, Rio de Janeiro: Vozes, 2017.

GONZALEZ, Lélia. A categoria político-cultural de amefricanidade. Tempo Brasileiro, Rio de Janeiro, n. 92/93, 1988, (p. 69-82). 
Lopes, M. L., Pacheco, A. C. L., Ativismo Negr@: entrecruzando epistemologias feministas nas trajetórias de mulheres negras e religiosas. ODEERE, v. 6, n. 01, jan./jun., p. 38-66, 2021. https://doi.org/10.22481/odeere.v6i01.8734

GONZALEZ, Lélia. Por um feminismo afro-latino-americano: ensaios, intervenções e diálogos. RIOS, Flávia; LIMA, Márcia (Orgs.). Rio de Janeiro: Zahar, 2020.

GONZALEZ, Lélia. Racismo e sexismo na cultura brasileira. Revista Ciências Sociais Hoje, v. 2, 1984, (p. 223-244).

GONZALEZ, Lélia. A mulher negra na sociedade brasileira. In: . Primavera para as rosas negras: Lélia Gonzalez em primeira pessoa. Rio de Janeiro: Diáspora Africana, UCPA, União dos Coletivos Pan-Africanistas, 2018, (p. 34-53).

KILEUY, Odé; OXAGUIÃ, Vera. O candomblé bem explicado: nações bantu, iorubá e fon. Rio de Janeiro: Pallas Editora, 2009.

KOFES, Suely. Experiências sociais, interpretações individuais: histórias de vida, suas possibilidades e limites. Cadernos Pagu, n. 3, 1994, (p. 117-141).

KOFES, Suely. Narrativas biográficas: que tipo de antropologia isso pode ser? In: KOFES, Suely; MANICA, Daniela (org). Vida e grafia: narrativas antropológicas entre biografia e etnografia. Rio de Janeiro: Lamparina Editora, 2015, (p. 20 -38).

KOFES, Suely; PISCITELLI, Adriana. Memórias de "histórias femininas, memórias e experiências". Cadernos Pagu, v. 8, 1997, (p. 343-354).

LANDES, Ruth. A cidade das mulheres. Rio de Janeiro: Civilização Brasileira, 1967.

LOURO, Gaucira Lopes. Pedagogias da sexualidade. In: . O corpo educado: pedagogias da sexualidade. Belo Horizonte: Autêntica Editora, 2019, (p. 9-42).

LUGONES, María. Rumo a um feminismo descolonial. Revista Estudos Feministas, v.22, 2014, (p. 935-952).

MACHADO, Maria das Dores Campos. Corpo e Moralidade Sexual em Grupos Religiosos. Estudos Feministas, n.1,1995, (p. 7-27).

PACHECO, Ana Cláudia Lemos. Mulher negra: afetividade e solidão. Salvador: Edufba, 2013.

ROSADO, Maria José Nunes. Direitos, cidadania das mulheres e religião. São Paulo: Tempo social, v. 20, 2008, (p. 67-81).

SANTOS, Cristiane Batista da S. "Um vivo demônio capaz de sugerir as maiores desordens": mulheres bem e mal procedidas em pecados no sul da capitania da Bahia. ODEERE: Revista do Programa de Pós-Graduação em Relações Étnicas e Contemporaneidade, v. 4, 2019, (p. 68-100).

SANTOS, Cristiane Batista da Silva. Entre o fim do império da farinha e início da república do cacau: negros em festas, sociabilidades e racialização no sul da Bahia (1870-1919). Tese de Doutorado (Doutorado em Estudos Étnicos e Africanos), Universidade Federal da Bahia, Salvador-Bahia, 2015. 
Lopes, M. L., Pacheco, A. C. L., Ativismo Negr@: entrecruzando epistemologias feministas nas trajetórias de mulheres negras e religiosas. ODEERE, v. 6, n. 01, jan./jun., p. 38-66, 2021. https://doi.org/10.22481/odeere.v6i01.8734

SIQUEIRA, Lourdes. Iyami lya Agbas dinâmica da espiritualidade feminina em templos afrobaianos. Revista Estudos Feministas, v. 3, 1995, (p. 436-445).

STOLKE, Verena. O enigma das interseções: classe," raça", sexualidade: a formação dos impérios transatlânticos do século XVI ao XIX. Revista Estudos Feministas, v. 14, 2006, (p. 15-42).

TABORDA, Francisco S. j. Feminismo e teologia feminista no primeiro mundo: breve panorâmica para uma primeira informação. Perspectiva Teológica, Belo Horizonte, v. 22, 1990, (p. 311-337).

TOMITA, Luiza E. Da exclusão a objeto de prazer: o corpo das mulheres oferece notas para uma reflexão teológica feminista. Mandrágora, v. 13, 2007, (p. 45-51).

WERNECK, Jurema Pinto. Samba segundo as ialodês: mulheres negras e a cultura midiática. Tese de Doutorado (Doutorado em Comunicação), Universidade Federal do Rio de Janeiro, Rio de Janeiro, 2007.

ZENICOLA, Denise Mancebo. Performance e ritual: a dança das labás no Xirê. Rio de Janeiro: Mavad Editora, 2014.

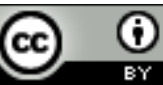

This work is licensed under a Licence Creative Commons Attribution 4.0 International License.

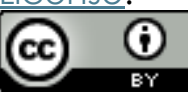

Este trabalho está licenciado com uma Licença Creative Commons - Atribuição 4.0

Internacional. 